\title{
The Expulsion of Resident Colombian Nationals during the Colombia-Venezuela Border Dispute: An "Under the Radar" Case for Diplomatic Protection of Human Rights?*
}

\section{La expulsión de residentes colombianos durante la crisis fronteriza entre Colombia y Venezuela: un caso inexplorado para la protección diplomática de derechos bumanos}

Robert-Joseph-Blaise MacLean

Universidad del Rosario, Colombia

robert.maclean@urosario.edu.co

ORCID: http://orcid.org/0000-0003-1372-2945

Walter Arévalo-Ramirez

Universidad del Rosario, Colombia

walter.arevalo@urosario.edu.co

ORCID: http://orcid.org/0000-0002-8501-5513
DOI: https://doi.org/10.11144/Javeriana.vj138.ercn Redalyc: http://www.redalyc.org/articulo.oa $? \mathrm{id}=82559799004$

\begin{abstract}
:
While International Humanitarian, Refugee and Human Rights Law are frequently resorted to in the search for remedies for human rights violations, the Public International Law remedy of Diplomatic Protection is often forgotten, perhaps because there are few cases fitting the legal requirements for that remedy. The Venezuelan expulsions and property confiscations in 2015 and 2017 of Colombian residents without due process and, frequently, with violence may provide a useful example of an appropriate case for Diplomatic Protection arising within the context of a forced expulsion of an identifiable nationality. The following article, result of a research project regarding international law enforceability, reviews the current law on Diplomatic Protection and, within the context of a factual survey of the treatment of Colombian nationals by Venezuela, undertakes an analysis as to whether the facts of the case in fact give rise to a remedy of Diplomatic Protection. Effectively, the article argues in favour of the availability of this remedy as an option for the Colombian government.
\end{abstract}

Keywords: Diplomatic Protection, State Responsibility, Internationally Wrongful Act, Remedy, Nationality.

\section{Resumen:}

Si bien frecuentemente se recurre al derecho internacional humanitario, al derecho de los refugiados y a los derechos humanos para enfrentar, juzgar y remediar las violaciones a los derechos humanos, a menudo se olvida el recurso de protección diplomática propio del Derecho Internacional Público, posiblemente porque son pocos los casos que se ajustan fácilmente a los requisitos doctrinales y legales para este recurso. Las expulsiones desde Venezuela y las confiscaciones de bienes entre 2015 y 2017 a ciudadanos colombianos, sin observar el debido proceso y, con frecuencia, con violencia, pueden ser un ejemplo útil de un caso apropiado para la protección diplomática surgido en el contexto de la expulsión forzada de una nacionalidad particular. El siguiente artículo, resultado de un proyecto de investigación sobre la eficacia del derecho internacional, revisa el derecho sobre la Protección Diplomática y, en el marco de un estudio fáctico del tratamiento de los nacionales colombianos por parte de Venezuela, analiza si los hechos del caso dan lugar a un recurso de protección diplomática. Tras estudiar su naturaleza, requisitos y doctrina, efectivamente, el artículo argumenta a favor de la disponibilidad de este remedio como una opción para el gobierno colombiano para proteger a sus ciudadanos en este caso.

Palabras clave: Protección Diplomática, Responsabilidad internacional del Estado, Hecho Internacionalmente Ilícito, Derechos Humanos, Nacionalidad.

\section{Introduction}

The Public International Law remedy of Diplomatic Protection is one which, while interesting from an academic perspective and a riveting subject for international public law classes and moot courts, is one that finds rare opportunity for practical application. Indeed, when the International Law Commission's (ILC) first Special Rapporteur on Diplomatic Protection, Dr. Mohamed Bennouna, issued his Preliminary Report, 
he took the view, in light of the development of other remedies for the protection of individual rights, and because in many ways Diplomatic Protection was constructed on a foundation of legal fictions, that it had outlived its usefulness. ${ }^{1}$

Following his appointment to the International Court of Justice (ICJ), Dr. BENNOUNA was replaced by Professor JOHN DUGARD as Special Rapporteur on Diplomatic Protection. Prof. DUGARD's views on the value of diplomatic protection as a remedy were significantly different than those of Dr. BENNOUNA. In his First Report on Diplomatic Protection, ${ }^{2}$ Prof. DUGARD stated that valuable legal institutions such as diplomatic protection ought not to be discarded merely because they are built upon legal fictions ${ }^{3}$. He stated that diplomatic protection could provide a valuable tool for the defence of human rights, saying:

Until the individual acquires comprehensive procedural rights under international law, it would be a setback for human rights to abandon diplomatic protection. ${ }^{4}$

Since the year 2000, when Prof. DUGARD wrote his First Report, opportunities to explore the relevance of diplomatic protection as a remedy for the protection of human rights have been rare.

But perhaps one has now arisen.

During the autumn of 2015 the world witnessed the expulsion from Venezuela of Colombian nationals by Venezuelan authorities through the application of force and without legal process. This was accompanied by the confiscation and destruction of their personal property in the absence of any sort of due process, the separation of families and the reported physical mistreatment of Colombians by Venezuelan authorities among other abuses. On a lesser scale, the same behavior by Venezuelan authorities has been repeated during 2016 and 2017, ${ }^{5}$ during the months of June and July of 2016, Venezuelan citizens started massive migrations (heavily controlled and condemned by Venezuelan authorities), to acquire basic living resources. ${ }^{6}$ By July 2017, Venezuelan authorities allegedly used excessive force against demonstrators that opposed a constituent assembly advanced by the executive, which results were questioned worldwide. The Colombian President Juan Manuel Santos [2010-2014, 2014-2018] announced (along with other countries of the hemisphere) that he would not recognize the election, a bold move that might bring as a consequence future threats to Colombian nationals in Venezuelan territory. ${ }^{7}$ This scenario raises issues as to what steps Colombia may take to protect these victims.

The approach taken by the Colombian government has inspired little confidence that they had a clearheaded and coherent strategy (the need for a policy regarding the humanitarian protection of Colombian overseas has been discussed by many authors of that country ${ }^{8}$ ). Some steps taken by the Colombian government in response include the following:

- The President and other politicians visited the border area to express sympathy to the victims.

- It tried to initiate local level discussions among local leaders.

- It suggested negotiation with the Venezuelans (about what is unclear).

- It sent the Foreign Minister to meet with the Venezuelan Chancellor, which produced no visible results.

- It established an emergency "humanitarian corridor" to assist its nationals fleeing Venezuela via official migratory points as well as through routes such as river crossings or rural fields. It has also attempted to protect the thousands of Colombians that live in Colombian border cities such as Cúcuta, but study or work on the Venezuelan side. ${ }^{9}$

- It sought the assistance of the Organization of American States (OAS) to have a conference of OAS Foreign Ministers, which was refused.

- The Colombian President attempted to phone the Venezuelan President Nicolás Maduro, which call was not answered, possibly because Maduro and his foreign minister had left on an Asian tour. 
The one concrete step taken by Colombia is to offer Colombian nationality to Venezuelan family members of expelled Colombians who wish to join their family members in this country. This is a nice gesture regarding family reintegration that complies with many international recommendations regarding repatriation, ${ }^{10}$ but does nothing to assert Colombian rights vis-à-vis its victimized nationals.

Colombia, in order to determine, in a clear-headed way, what steps ought to be taken must know its legal options. Once it is clear as to what it may do it can then choose what tool or selection of tools it may choose to apply in tandem with a political and publicity strategy.

Although much of the public discussion about legal responses have revolved around resorting to the OAS, UNASUR and bilateral discussions (the mayor of Cúcuta indicated in a radio interview that he had referred charges against Nicolás Maduro to the Chief Prosecutor of the International Criminal Court ${ }^{11}$ ) and as to what remedies may exist regarding human rights violations, there is a public international law remedy which seems not to have been considered but which appears designed to deal with the specific type of situation today facing Colombia. It is the figure of Diplomatic Protection.

In the following article, we will explore the issue in the following manner. First, we will review the law of Diplomatic Protection as it currently applies in international law. Secondly we will examine the ways in which it may be applied. Thirdly, we discuss the remedies and forum that may be available within the current context.

\section{What is diplomatic protection?}

The first point to clarify is that Diplomatic Protection has nothing to do with Diplomatic Immunity, which is immunity from prosecution accorded by international law to diplomats operating in foreign countries. ${ }^{12}$ While Diplomatic Immunity is today regulated by the Vienna Conventions on Diplomatic Immunity and on Consular Relations, the principle of diplomatic protection arises out of the essential sovereignty of the state itself, and is founded upon the historic right of states to act in protection of their citizens. ${ }^{13}$ Diplomatic Protection is the right of a state to protect its nationals when they are being victimized illegally by a foreign state in which they happen to be present. ${ }^{14}$ The right is that of the state, not the victims, but arises out of the concept that an offence against a state's nationals is an offence against the state itself.

The Permanent Court of International Justice provided the jurisprudential starting point, in the Mavrommatis Palestine Concessions ${ }^{15}$ case stating:

It is an elementary principle of international law that a State is entitled to protect its subjects when injured by acts contrary to international law by another State from whom they have been unable to obtain satisfaction through the ordinary channels. By taking up the case of one of its subjects and by resorting to diplomatic action or international judicial proceedings on his behalf, a State is in reality asserting its own right - its right to ensure, in the person of its subjects, respect for the rules of international law. 16

As noted above, notwithstanding Dr. BENNOUNA's conclusion that diplomatic protection was an outdated remedy, the ILC appointed Prof. DUGARD to succeed him as Special Rapporteur on Diplomat Protection, and DUGARD in $2000{ }^{17}$ recognized the remaining importance of diplomatic protection in spite of its flaws, including it being a remedy sought by the State and the possible legal fictions underlying it:

20. The fictitious nature of diplomatic protection was a prominent feature of Mr. Bennouna's preliminary report in which he asked the Commission for guidance on the question whether a State in bringing an international claim was \# enforcing its own right or the right of its injured national.\# 21. The present Special Rapporteur does not share his predecessor's disdain for fictions in law. Most legal systems have their fictions. Indeed Roman law relied heavily on procedural fictions in order to achieve equity. \#The life of the law is not logic, but experience\#, in the words of Oliver Wendell Holmes, the late Supreme Court Justice of the United States. An institution, like diplomatic protection, that serves a valuable purpose should not be dismissed simply on the ground that it is premised on a fiction and cannot stand up to logical scrutiny. ${ }^{18}$ 
He also recognized the lack, at the international level, the existence of substantive individual procedural rights and, for that reason observed that diplomatic protection as a remedy needed to be preserved:

Until the individual acquires comprehensive procedural rights under international law, it would be a setback for human rights to abandon diplomatic protection. ${ }^{19}$

It may hold attraction to some that an individual should have the personal right to make the claim for Diplomatic Protection for a violation of one's personal human rights, but it is the classic view that prevails. This view holds that it is the State's right that is being enforced, and that the victim has no right to have diplomatic protection enforced on his behalf. ${ }^{20}$ Thus, it is entirely within the State's own discretion and procedures to decide whether or not it will seek satisfaction as a result of the wrong committed against its national. This of course is the preferable position for a state, as it permits it to decide which cases it wishes to advance. Consequently, international law recognizes no human right to diplomatic protection. ${ }^{21}$

Since, conceptually, it is the state that is the victim of these wrongs ${ }^{22}$ it is, therefore, the state's decision to apply for the remedy if the conditions to do so are met. Thus, with respect to any alleged violations by Venezuela, the Colombian government has the onus of deciding if they wish to seek this remedy on its own behalf arising from the alleged wrongs committed against its nationals. Further, since the Venezuelan actions are clear violations of their human rights, Diplomatic Immunity may be tailor-made for seeking recompense, particularly as the Colombian state has more resources than the victims themselves to pursue any claim.

\section{Under what conditions diplomatic protection may be invoked? Do they apply in this case?}

According to well established international law the following are the conditions under which Diplomatic Protection may be invoked:

\section{The offence complained of must be an "international wrong"}

In order that a claim of diplomatic protection may arise, the act complained of must rise to the level of an international wrong, that is, a violation of that State's obligations under international law.

The legal standard is the subject of debate. There are those who would argue in favour of a "national treatment" standard meaning that nationals and non-nationals of the offending state must be treated alike. ${ }^{23}$ The better view is that States must meet an "international standard", meaning that the treatment accorded to foreign nationals within a State's borders must not be such as to offend the broader international community.

${ }^{24} \mathrm{~A}$ broadly accepted statement of the standard is as follows:

The treatment of an alien, in order to constitute an international delinquency, should amount to an outrage, to bad faith, to wilful neglect of duty or to an insufficiency of governmental action so far short of international standards that every reasonable and impartial man would recognize its insufficiency. 25

COLIN WARBRICK credits this test as being precise and demanding and presenting a clear distinction from various tests existing under human rights law. ${ }^{26}$ It is an attractive case as applied to the Colombian victims of the Venezuelan expulsion because, under this test claims may be sustained for uncompensated property confiscation, liberty deprivation and denial of due process and "justice". ${ }^{27}$

In other words, the question is whether Venezuela is committing acts which are illegal at international law. On the face of it, there appear to be multiple offences being committed. A partial list would appear to include the following: 
Expropriation without compensation. ${ }^{28}$ Many of the people expelled have residences constructed within Venezuela. Those marked with the letter "D" are set for demolition. ${ }^{29}$ Consequently, there is a destruction and confiscation of private property of the victims without any underlying legal process legalizing it, any process allowing the assertion of legal rights by the victims and without compensation. Furthermore, they leave with what they can carry. Photos of men carrying refrigerators on their backs are heartbreaking, but imagine what they have had to leave behind. Even if it is only photos and family mementoes it is a tragedy. When it is children it is a crime.

Forced displacement. These individuals are being removed by force. They have no choice as to whether to leave. They leave with such possessions as they can carry. When there are families made up of Colombians and Venezuelans, the Colombian national must leave, thus dividing families. This constitutes a violation of the International Covenant on Civil and Political Rights. ${ }^{30}$ Article 13 of the Covenant provides as follows:

An alien lawfully in the territory of a State Party to the present Covenant may be expelled therefrom only in pursuance of a decision reached in accordance with law and shall, except where compelling reasons of national security otherwise require, be allowed to submit the reasons against his expulsion and to have his case reviewed by, and be represented for the purpose before, the competent authority or a person or persons especially designated by the competent authority. ${ }^{31}$

\section{The Convention was ratified by Venezuela in $1978 .{ }^{32}$}

Failure to afford to the affected Colombians due process rights. The expulsion of the Colombians is being done at the point of a gun. There is no legal notice, no hearing or other process in existence under which they may assert their rights or under which the Venezuelan state must justify, ${ }^{33}$ under a law, the acts they are undertaking.

It is important to be clear that the actions of the Venezuelan authorities do not amount to "deportation". As local sources have noted: "Deportation is the right of every sovereign state to solicit the exit from its territory of every person found there in a condition of illegal migration (translation)". ${ }^{34}$ This is relevant considering most of the Colombians that have been subject to this measures have residency documents (or had, since massive revocations have taken place), had been residing in Venezuela with the knowledge and acquiescence of Venezuelan authorities for many years, they have not committed any migratory faults, and therefore are not subject to legal deportation.

The conduct of Venezuelan authorities amounts to "expulsion" 35 which is illegal under international law according to Human Rights Committee "jurisprudence, ${ }^{36}$ in its interpretation of the ICCPR, the General Comment 31 [80] of 29 March 2004, ${ }^{37}$ and other sources, including Article 22(8) of the American Convention on Human Rights:

ICCPR General Comment 31 [80] views on expulsion extend the prohibition on the Covenant regarding expulsion to different types of irreparable damage:

The jurisprudence of the Committee has been reinforced by General Comment 31/80 of 29 March 2004 on the nature of general legal obligations imposed on State parties to the Covenant. Indeed, the Committee stated that \#the article 2 obligation requiring that State parties respect and ensure the Covenant rights for all persons in their territory and all persons under their control entails an obligation not to extradite, deport, expel or otherwise remove a person from their territory, where there are substantial grounds for believing that there is a real risk of irreparable damage, such as that contemplated by articles 6 and 7 of the Covenant, either in the country to which removal is to be effected or in any country to which the person may be subsequently removed\#. In the same General Comment, the Committee added that \#the relevant judicial and administrative authorities should be made aware of the need to ensure compliance with the Covenant obligations in such matters\#. One should also note that the Committee has suggested that women should not be sent back to States where they are likely to be subjected to forced female genital mutilation and that such deportations would amount to violations of article 7.38

Failure to afford to the affected Colombians legal treatment similar to that afforded Venezuelans within the country. It is a norm of international law that foreigners within a state must be treated equally under the law with nationals. As stated above, Colombians are being segregated from Venezuelan nationals and being expelled arbitrarily because and only because of their nationality. 39

Ethnic cleansing. While we liken the term ethnic cleansing to the horrors witnessed during the breakup of the former Yugoslavia, or perhaps during the Rwandan genocide, the reality is that ethnic cleansing is not a question of "quantity" but "quality". The reality is that the people being expelled are Colombians and they are specifically being expelled as a result of their nationality. Accordingly it is irrelevant whether the number is 10, 10,000 or 10,000,000; the point is that the Venezuelan state seeks to cleanse the designated areas of its Colombian inhabitants.

A violation of the probibition against collective punishment. Even if the Venezuelan President's comments that the steps taken are to combat "paramilitaries" and criminal organizations, it is impossible to believe that the children being separated from their parents form any part of such groups. 
Battery. There are documented reports of physical beatings of Colombians by Venezuelan authorities and reports as well of sexual assaults by members of the Venezuelan forces against Colombian women. If verified, these too would constitute violations of multiple international norms, beginning with the Geneva Conventions of $1949^{40}$ and continuing on up to the Rome Statute ${ }^{41}$, which in addition to torture, rape and "Other inhumane acts of a similar character intentionally causing great suffering, or serious injury to body or to mental or physical health specifically includes 'Deportation or forcible transfer of population' means forced displacement of the persons concerned by expulsion or other coercive acts from the area in which they are lawfully present, without grounds permitted under international law" as conduct constituting a crime against humanity under art 7 paragraph 1. (The Rome Statute was ratified by Venezuela in June 2000).

It is important to note that, since the expulsions have been sudden, without notice and without due process of any form, the International Covenant on Civil and Political Rights has been, prima facie, violated. 42 As sources of local analysis have pointed, Venezuela is obliged to provide the subjects of the expulsion "...an opportunity to defend themselves in a hearing on immigration measures and, within the context of other norms of the Covenant, whether the expulsion is for reasons of race or nationality... (translation)". 43 Accordingly, it would appear clear that the prerequisite condition of an international wrong having been committed has been met.

\section{The "international wrong" complained of must be attributable to the offending state}

Under this branch of the law, the illegal acts must be attributable to the state. Given the pronouncements of the Venezuelan president regarding his order to conduct these operations, the defence of these actions by Venezuelan officials and the carrying out of these actions by uniformed members of the Venezuelan police and armed forces, there is no doubt that these acts are those of the Venezuelan state. ${ }^{44}$

Under the doctrine of State Responsibility, codified in the Draft Articles on Responsibility of States for Internationally Wrongful Acts by the International Law Commission (2001), the guiding principles regarding attribution of a Conduct to a State are developed in Chapter II, and begin by attributing the Conduct of an organ of the State, to the State as an entity of international law:

(Article 4. The conduct of any State organ shall be considered an act of that State under international law, whether the organ exercises legislative, executive, judicial or any other functions, whatever position it holds in the organization of the State, and whatever its character as an organ of the central Government or of a territorial unit of the State). ${ }^{45}$

This criteria of attribution proclaimed in Art. 4, would be fulfilled when the expulsions and other illegal acts are committed by the Venezuelan National Army, the Venezuelan administrative and migratory authorities (SAIME, Servicio Administrativo de Identificación, Migración y Extranjería de Venezuela), or Police Forces of one of its Federal entities such as the Police of the Tachira State.

Additionally, other attribution criteria might be applicable in this case, such as Art. 5 (Article 5. Conduct of persons or entities exercising elements of governmental authority: he conduct of a person or entity which is not an organ of the State under article 4 but which is empowered by the law of that State to exercise elements of the governmental authority shall be considered an act of the State under international law, provided the person or entity is acting in that capacity in the particular instance). In the case of Political militia (Guardia Venezolana) that was commanded to aid the police, or finally, under Art. 8 (Article 8. Conduct directed or controlled by a State: The conduct of a person or group of persons shall be considered an act of a State under international law if the person or group of persons is in fact acting on the instructions of, or under the direction or control of, that State in carrying out the conduct). Art. 8 would apply, on the face of it, to the acts committed by "colectivos": (spontaneous groups of political partisans of the PSUV party -Partido Socialista 
Unido de Venezuela-) that aided the authorities in the expulsion activities under an order or incitement of the Executive.

\section{Before Diplomatic Protection may be invoked, the victims must, under normal circumstances, have exhausted all legally available remedies within the offending state. For reasons set out below, there is an exception to this rule, which applies in this case}

Although there is doctrine and jurisprudence to suggest that the victim of the "wrong" must first have exhausted all local remedies, it is now clear that this requirement is not absolute; indeed, though a topic of discussion, it ought to be regarded as a mere procedural step that may, depending upon the case, need to be taken prior to invoking diplomatic protection. ${ }^{46}$ The key point is that it is unnecessary to use all the local remedies when they are obviously biased, lack integrity or do not meet an international standard. The International Court of Justice held, in the Electtronica Sicula case:

...for an international claim to be admissible it is sufficient if the essence of the claim has been brought before the competent tribunals and pursued as far as permitted by local law and procedure and without success. ${ }^{47}$

For reasons noted below, the extent of the "requirement to exhaust local remedies" falls beyond the reach of this paper, it is worth noting that this requirement does not apply when it is an exercise in futility. As DUGARD asserted in his Third Report, “...a claimant is not required to exhaust justice in a foreign state 'when there is no justice to exhaust"' ${ }^{48}$

As implied above, there is debate as to whether the "local remedies" issue is substantive law or a matter of procedure. ${ }^{49}$ This issue turns on whether the right to diplomatic protection exists independently of the exhaustion of local remedies component; in other words, the "international wrong" consists not only of the complained of act, but also the failure to exhaust the local remedies. In order to sustain that the exhaustion of local remedies requirement is a part of the substantive law, then the court proceedings (if they exist) of the respondent State comprise a component of the cause of action. ${ }^{50}$ This analysis conceives of two components to the cause of action, specifically the original wrong and the later denial of a judicial remedy (apart from those cases in which the denial of justice IS the actual cause). ${ }^{51}$ To apply this analysis to the ColombianVenezuelan situation, the right to diplomatic protection would arise from two events, namely, the expulsion/ confiscation acts of the Venezuelan state plus the failure of the Colombian victims to seek recourse within the Venezuelan judicial system.

As JAMES EDMUND SANDFORD FAWCETT frames it, this approach envisages no distinction between the cause of action and the right of to bring action; they are conjoined. ${ }^{52}$

Alternatively, the procedural view holds that the original international wrong (in this case the expulsions/ confiscations etc.) by themselves give rise to the right to claim diplomatic protection. These commission of these acts, in themselves, are the moment at which the right arises. Thus, on this view, the exhaustion of local remedies is merely a procedural step that ought to be completed before the right arises to bring the matter before an international tribunal such as the ICJ. This is a key question because, as pointed out by DUGARD in his Second Report:

...the critical time at which international responsibility arises will differ according to the approach adopted. If the rule is substantive, international responsibility will arise only after all local remedies have been exhausted, whereas international responsibility is incurred immediately on the commission of an internationally wrongful act if the rule is procedural. ${ }^{53}$ 
As to the issue between Colombia and Venezuela, however, the denial of justice is both one of the components of the alleged wrongs and on its own an alleged wrong. This is to say, to the extent that the very fact of expulsion, confiscation of property, family separation ${ }^{54}$ without any form of due process is, by itself, one of the alleged wrongs the requirement of the victims to avail themselves of local remedies ought to be considered a moot point. But even if the aspects of the wrongs which consist of property confiscation, family separation, illegal detention are considered apart from the failure to access local remedies, the procedural analysis appears to be more consistent with the above-noted comment of DUGARD, namely that local remedies need not be "exhausted" in the absence of any local justice.

Though the ILC, following the submission of Dugard's Second Report, failed to finally resolve the question, 55 as noted above the more internally consistent view of the local remedies rule is that it is merely a procedural matter. It would be unfortunate if the effect of the rule would be that violating States could eliminate a remedy through the expedient of committing another wrong, namely the denial of local, impartial justice dispensed by impartial judges in accordance with the rule of law.

In conclusion, it is generally considered that before Diplomatic Protection may be invoked the victims must have pursued all legal remedies available within the offending state. The exception to this rule is that it does not apply when there are no local remedies available. Local justice need not be sought when there is no local justice to seek. In this case, there is no legal process available to the victims. They have been, or are being expelled at gunpoint and by threat of bodily harm. Their houses are being designated for destruction arbitrarily and the so-called "Public Defenders" are in fact defending the Venezuelan state. In the absence of any legal processes to which the Colombians could resort, this requirement cannot apply.

\section{The victims must be nationals of the complaining state, at the time both of the commission of the wrong and at the time of the lodging of the complaint, 56 and may not possess a dual nationality which includes that of the offending state}

While, as the late IAN BROWNLIE pointed out, it was beyond debate that diplomatic protection may only be claimed by a State in respect of its nationals, ${ }^{57}$ in the modern globalized world a more difficult issue arises in respect of which nationals may a State exercise diplomatic protection.

This issue came before the Permanent Court of International Justice (PCIJ) in the 1939 the PanevezysSaldutiskis Railway Case ${ }^{58}$ where it found as follows:

In the opinion of the court... by resorting to diplomatic action or international judicial proceedings on his behalf, a State is in reality asserting its own right, the right to ensure in the person of its nationals respect for the rules of international law. This right is necessarily limited to intervention on behalf of its own nationals because in the absence of a special agreement, it is the bond of nationality between the State and the individual which alone confers upon the State the right of diplomatic protection... 59

In such cases, compensation is measured by assessing the damage suffered by the victim/national, as opposed by the state bringing the claim. ${ }^{60}$ The key point here is that it is the nationality itself that creates the bond between the individual and the state, and the manner of acquisition or exercise forms no part of the basis for the claim of diplomatic protection. This is evidenced by the fact that, in the case of dual nationals, diplomatic protection may not be exercised by the state of naturalization against the state of birth it can be exercised against any other state. Thus, diplomatic protection can be exercised on behalf of naturalized citizens. Thus, it is the Nationality itself, regardless of how attained, which creates a bond between the individual and the State which gives rise to the State's right of diplomatic protection. 
The mobility of peoples throughout the $20^{\text {th }}$ century led to an increasing complexity to issues of nationality as the world became an international community in which people moved between States with greater ease. Human migration, whether legal and illegal, formal and informal, documented and undocumented are not the only modern phenomena that States must contend with. There are issues of protection of refugees, asylum ${ }^{61}$ combined with increased convenience in capital transfers and the development of transnational corporations which have given rise to ambiguities in terms of nationality. States, with greater frequency than in the days of Mavrommatis, when the jurisprudence on diplomatic protection was born, are confronted with dealing with non-nationals (both corporeal and incorporeal) within their borders. In the particular case of Colombia and Venezuela, the situation involves Colombian nationals residing within the borders of Venezuela, often with Venezuelan spouses and children and with employment there. Frequently, these individuals have been able to establish themselves inside Venezuela for many years without appropriate legal documentation and, arguably, given to the openness of their presence, with the complicity of Venezuelan officials.

The importance of the dual nationality issue arises when individuals flee oppressive States to those whose societies are characterized by due process and respect for human rights. Such individuals may take on a new nationality in their adopted country while retaining their former nationality as well. In a number of cases, the former states do not recognize the new nationality or even treat it as illegal. ${ }^{62}$ If such a person chooses to return, even temporarily to their former state and become a victim of an "international wrong" the lack of clarity surrounding the rules of diplomatic protection make it unlikely that the state of the person's new nationality could seek diplomatic protection on his or her behalf.

Another factor to be considered is whether the nationality of the Colombian victims was "effective".

The subject of "nationality" leads inevitably to the Nottebohm Case ${ }^{63}$ in which Liechtenstein sought to enforce diplomatic protection against Guatemala in respect of alleged expropriations of property of Mr. Friedrich Nottebohm, a German-born naturalized Lichtenstein citizen by Guatemala, a state where he had resided most of his life. His 1939 Liechtenstein naturalization was so apparently abbreviated that it raised questions of its legitimacy. ${ }^{64}$

On the question as to whether Nottebohm's "nationality" in Liechtenstein was sufficient to found the remedy of diplomatic protection, the ICJ followed an analysis which did not question a State's right to grant nationality, for its own purposes, on any basis it so chose, but that a separate standard would apply for purposes of international recognition of such nationality. In order for Liechtenstein to claim diplomatic protection against Guatemala, according to the ICJ, a genuine link between them, would have to exist.

The Court said:

Nationality is a legal bond having as its basis a social fact of attachment, a genuine connection of existence, interests and
sentiments together with the existence of reciprocal rights and duties. It may be said to constitute the juridical expression
of the fact that the individual upon whom it is conferred is in fact more closely connected with the population of the state
conferring the nationality than with that of any other State. Conferred by a State, it only entitles that State to exercise
protection vis-a-vis another State, if it constitutes a translation into judicial terms of the individual's connection with the
State that made him its national. 65

To assess whether nationality is "effective" for purposes of international law, the court noted as useful various indicia such as habitual residence (characterized as important), family ties, participation in the public life of the state, and general "attachment" to the new State. ${ }^{66}$

The ICJ's denial of the diplomatic protection claim in the Nottebohm case has resulted in legal commentators focussing on the issue of "effective link" and concluding that this is now preferred lens through which to view claims for diplomatic protection of dual nationals. ${ }^{67}$ The key point as regards the Colombian victims is that not only are they not "dual nationals", they have an effective link with Colombia, having been 
born there. Accordingly, any issue of "effective nationality" of the Colombians arising from the longevity of their residence in Venezuela would be a red-herring.

In this respect, Venezuelans have specifically selected their victims under criteria which excludes dual nationals. Only single nationality Colombians have been affected by the Venezuelan actions, which is to say, only those individuals who are Colombian nationals (although present inside Venezuela) are expelled. Neither Venezuelan nationals nor Colombians with dual Venezuelan Colombian nationality are expelled. Accordingly, the facts appear to support this element of the test. Thus, the nationality requirement would appear to pose no obstacle to any proposed Colombian claim.

\section{The "Clean Hands" Issue}

One claim advanced by the Venezuelans in justification for the expulsions is that many of the Colombians are involved in criminal activities along the Colombian-Venezuelan border, such activities including smuggling and participation in alleged "Para-Military" activities.

Although some sources contend that the injured national must come to court with "clean hands", that is to say that the injured alien must himself not have caused the wrong by virtue of his own conduct, this appears to be a misstatement of the current state of the law. In his Sixth Report on Diplomatic Protection, ${ }^{68} \mathrm{JOHN}$ R. DUGARD concludes it is highly questionable whether "clean hands" constitutes a precondition before a State may invoke diplomatic protection. ${ }^{69}$

Accordingly, it would appear that, even if such a requirement ever existed, the evolution of the law has overtaken it such that it would not apply.

\section{Who may bring the claim?}

The theory of Diplomatic Protection is that even though the wrong is perpetrated against nationals of the complaining state, it is the state itself against which the wrong has been committed. In other words, individuals may not bring the claim. The state may bring the claim if it chooses to do so, and when it does, it does on its own behalf and not on behalf of the victims. Obviously the state may choose, in its claim, to seek compensation which it may then decide to allocate to the victims, but that is a matter within the discretion of the state. Accordingly, any claim for Diplomatic protection in this case may only be brought by the Colombian state.

\section{Remedies}

There are no clear rules on what remedies may be sought under such a claim. Colombia may seek compensation for the property of Colombian nationals lost or destroyed in the expulsions, compensation for the costs of housing and relocating them, medical costs, as well as costs relating to the pain and suffering of the victims. It may also, or even just as an alternative, seek a denunciation of the Venezuelan state through a finding that their acts have violated international law. Such denunciations have, in the past, been held to constitute a sufficient remedy. 


\section{Forum}

Since this remedy is quintessentially a matter of public international law, the most appropriate forum is the International Court of Justice, ICJ. While there have been arbitrations which have applied the figure of Diplomatic Protection, it is unlikely that any such tribunal between Colombia and Venezuela will be established. Thus Colombia will need to look to the ICJ if it wishes to pursue this remedy. Venezuela has not submitted a jurisdiction declaration to the ICJ.

A difficulty arises here because Colombia has taken steps to withdraw from the jurisdiction of the ICJ. Accordingly, if Colombia wishes to bring an action before that body it will have to seek either permission, consent or a relevant treaty of convention under which Colombia has agreed to the ICJ as the dispute settling mechanism. In this sense, the fact that Colombia is a part of the International Covenant on Civil, Political and Economic Rights will be useful in order to advance such a claim because many of the international wrongs being committed by Venezuela in fact arise as violations of this Convention.

\section{Conclusion}

As a result of the foregoing it is clear that there is at least one major international law remedy which is likely available to Colombia. In order to deal with the current crisis with Venezuela, which has clearly been instigated by the neighbouring state, Colombia must adopt a clearly thought out strategy taken in full awareness of all its options. While to date there is much commentary that this approach is still in development by Colombian authorities, they would be well advised to consider Diplomatic protection as one of the tools in their toolkit.

\section{Bibliography}

\section{Books}

BROWNLIE, IAN, Principles of Public International Law (6th ed., Oxford University Press, Oxford, 2003).

CRAWFORD, JAMES, The International Law Commission's Articles on State Responsibility. Introduction, Text and Commentaries (Cambridge University Press, Cambridge, 2002).

HENCKAERTS, JEAN-MARIE, Mass Expulsion in Modern International Law and Practice (International Studies in Human Rights, volume 41, Martinus Nijhoff Publishers, The Hague, Boston, London, 1995).

\section{Contributions in collective books}

MACLEAN, ROBERT JOSEPH BLAISE, Fresh Hay from Old Fields: the Continuing Usefulness of Diplomatic Protection, in Derecho internacional contemporáneo: lo público, lo privado, los derechos humanos: liber amicorum en homenaje a Germán Cavelier, 230-246 (RICARDO ABELLO-GALVIS, ed., Universidad del Rosario, Bogotá, 2006). Available at: http://www.anuariocdi.org/contemporaneo/1_9_fresh\%20hay.pdf

\section{Journals}

DUCHESNE, MATTHEW S., The Continuous-Nationality-of-Claims Principle: Its Historical Development and Current Relevance to Investor-State Investment Disputes, 36 George Washington International Law Review, 4, 783-816 (2004).

FAWCETT, JAMES EDMUND SANDFORD, The Exhaustion of Local Remedies: Substance or Procedure?, 31 British Yearbook of International Law, $452-458$ (1954). 
GIBNEY, MATTHEW J., Is Deportation a Form of Forced Migration?, 32 Refugee Survey Quarterly, 2, 116-129 (2013). https://doi.org/10.1093/rsq/hdt003

HECKMAN, GERALD, International Law and Procedural Safeguards in Deportation Proceedings: Ahani v. Canada, 17 Revue Québécoise de Droit International, 2, 81-122 (2000). Available at: https://www.sqdi.org/wp-content/ uploads/17.2_-_heckman.pdf?x85994

LEIGH, GUY I. F., Nationality and Diplomatic Protection, 20 International \& Comparative Law Quarterly, 3, 453-475 (1971). https://doi.org/10.1093/iclqaj/20.3.453

MEINDERSMA, CHRISTA, Violations of Common Article 3 of the Geneva Conventions as Violations of the Laws or Customs of War under Article 3 of the Statute of the International Criminal Tribunal for the Former Yugoslavia, 42 Netherlands International Law Review, 03, 375-397 (1995). https://doi.org/10.1017/S0165070X00005891

OSORIO-TORRES, AURA XIMENA, Los derechos de los colombianos en el extranjero y de los extranjeros en Colombia. En mora de un enfoque integral, 117 Vniversitas, 357-376 (2008). Available at: https://revistas.javeriana.edu.co /index.php/vnijuri/article/view/14548

ROBINSON, DARRYL, Defining \#Crimes against Humanity\# at the Rome Conference, 93 American Journal of International Law, 1, 43-57 (1999). https://doi.org/10.2307/2997955

SHIRLEY, JONATHAN, The Role of International Human Rights and the Law of Diplomatic Protection in Resolving Zimbabwe's Land Crisis, 27 Boston College of International and Comparative Law Review, 1, 161-171 (2004). Available at: https://lawdigitalcommons.bc.edu/cgi/viewcontent.cgi?article=1124\&context $=\mathrm{icl}$

STARR, SONJA \& BRILMAYER, LEA, Family Separation as a Violation of International Law, 21 Berkeley Journal of International Law, 2, 213-287 (2003). https://doi.org/10.15779/Z388350. Available at: https://scholarship .law.berkeley.edu/cgi/viewcontent.cgi?article $=1239 \&$ context $=$ bjil

WARBRICK, COLIN, Protection of Nationals Abroad, 37 International \& Comparative Law Quarterly, 4, 1002-1012 (1988). https://doi.org/10.1093/iclqaj/37.4.1002

WARBRICK, COLIN \& MCGOLDRICK, DOMINIC, Diplomatic Representations and Diplomatic Protection, 51 International \& Comparative Law Quarterly, 3, 723-733 (2002). https://doi.org/10.1093/iclq/51.3.723

\section{International treaties}

ORGANIZATION OF AMERICAN STATES, OAS, American Convention on Human Rights, adopted in San José, Costa Rica, on 22 November 1969. Available at: http://www.oas.org/dil/treaties_B-32_American_Conv ention_on_Human_Rights.pdf

United Nations, International Covenant on Civil and Political Rights, ICCPR, adopted and opened for signature, ratification and accession by General Assembly Resolution 2200A (XXI) of 16 December 1966, entry into force 23 March 1976. Available at: https://www.ohchr.org/en/professionalinterest/pages/ccpr.aspx

United Nations, Vienna Convention of Diplomatic Relations (VCDR 1961), done at Vienna on 18 April 1961, entered into force on 24 April 1964. Available at: http://legal.un.org/ilc/texts/instruments/english/conventio ns/9_1_1961.pdf

\section{Documents, reports}

OFFICE OF THE UNITED NATIONS HIGH COMMISSIONER FOR HUMAN RIGHTS, OHCHR, Expulsions of Aliens in International Human Rights Law, Discussion paper, Geneva, September 2006. Available at: https://www.unhcr.org/protection/migration/4bf6813a9/ohchr-discussion-paper-expulsion-aliens-intern ational-human-rights-law.html

UNITED NATIONS HIGH COMMISSIONER FOR REFUGEES, UNHCR, Handbook for Repatriation and Reintegration Activities (UNHCR, Geneva, May 2004). Available at: https://www.refworld.org/docid/416bd 1194.html 
UNITED NATIONS, HUMAN RIGHTS COMMITTEE, HRC, General Comment 31 [80], The Nature of the General Legal Obligation Imposed on States Parties to the Covenant (CCPR/C/21/Rev.1/Add. 13, adopted on 29 March 2004). Available at: https://www.refworld.org/docid/478b26ae2.html

UNITED NATIONS, INTERNATIONAL LAW COMMISSION, ILC, Draft Articles on Responsibility of States for Internationally Wrongful Acts by the (Supplement No. 10 (A/56/10), chp.IV.E.1, November 2001). Available at: https://www.refworld.org/docid/3ddb8f804.html

UNITED NATIONS, INTERNATIONAL LAW COMMISSION, ILC, Preliminary Report on Diplomatic Protection, by Mr. MOHAMED BENNOUNA, Special Rapporteur (UN Doc. A/CN.4/484, 4 February 1998). Available at: http://legal.un.org/ilc/documentation/english/a_cn4_484.pdf

UNITED NATIONS, INTERNATIONAL LAW COMMISSION, ILC, First Report on Diplomatic Protection, by Mr.JOHN R. DUGARD, Special Rapporteur (UN Doc. A/CN.4/506 and Add. 1, 7 March and 20 April, 2000). Available at: http://legal.un.org/ilc/documentation/english/a_cn4_506.pdf

UNITED NATIONS, INTERNATIONAL LAW COMMISSION, ILC, Second Report on Diplomatic Protection, by Mr.JOHN R. DUGARD, Special Rapporteur (UN Doc. A/CN.4/514, 28 February 2001). Available at: htt p://legal.un.org/ilc/documentation/english/a_cn4_514.pdf

UNITED NATIONS, INTERNATIONAL LAW COMMISSION, ILC, Third Report on Diplomatic Protection, by Mr.JOHN R. DUGARD, Special Rapporteur (UN Doc. A/CN.4/523 and Add.1, 7 March and 16 April 2002). Available at: http://legal.un.org/ilc/documentation/english/a_cn4_523.pdf

UNITED NATIONS, INTERNATIONAL LAW COMMISSION, ILC, Sixth Report on Diplomatic Protection, by Mr. JOHN R. DUGARD, Special Rapporteur (UN Doc. A/CN.4/546, 11 August 2004). Available at: http://1 egal.un.org/ilc/documentation/english/a_cn4_546.pdf

\section{Case law}

International Court of Justice, ICJ, Barcelona Traction Light and Power Company Ltd. (Belgium v. Spain), Judgment of 5 February 1970, ICJ Reports, 1-54. Available at: https://www.icj-cij.org/files/case-related/50/050-197002 05-JUD-01-00-EN.pdf, https://www.icj-cij.org/en/case/50/judgments

International Court of Justice, ICJ, Elettronica Sicula S.p.A. Case (ELSI) (United States of America v. Italy), Judgment of 20 July 1989, ICJ Reports, 1-71. Available at: https://www.icj-cij.org/files/case-related/76/076-19890720-J UD-01-00-EN.pdf

International Court of Justice, ICJ, Nottebohm Case (Liechtenstein v. Guatemala) (second phase), Judgment of 6 April 1955, ICJ Reports, 1-27. Available at: https://www.icj-cij.org/files/case-related/18/018-19550406-JUD-01-0 0-EN.pdf

Mexico-US General Claims Commission, L. F. H. Neer and Pauline Neer (USA) v. United Mexican States (United States v. Mexico), 15 October 1926, 1926 Reports of International Arbitral Awards, RIAA IV, 60-66. Available at: http://legal.un.org/riaa/cases/vol_IV/60-66.pdf

Permanent Court of International Justice, PCIJ, Mavrommatis Palestine Concessions (Greece v. United Kingdom), Objection to the Jurisdiction of the Court, Judgment, PCIJ, Series A no 2, ICGJ 236, 30 August 1924, PCIJ 1924, 1-37. Available at: https://www.icj-cij.org/files/permanent-court-of-international-justice/serie_A/A_02 106_Mavrommatis_en_Palestine_Arret.pdf

Permanent Court of International Justice, PCIJ, The Panevezys-Saldutiskis Railway Case (Estonia v. Lithuania), Judgment of 28 February 1939 (Series A/B) No. 76 (1939), 1939 PCIJ, 1-23. Available at: https://www.icj-cij. org/files/permanent-court-of-international-justice/serie_AB/AB_76/01_Panevezys-Saldutiskis_Arret.pdf

United Nations, Human Rights Committee, Francesco Madafferi v. Australia, CCPR/C/81/D/1011/2001, 26 July 2004. Available at: https://tbinternet.ohchr.org/_layouts/treatybodyexternal/Download.aspx?symbolno=CC PR\%2FC\%2F81\%2FD\%2F1011\%2F2001\&Lang=en 


\section{Press and news articles}

ARÉVALO, WALTER, Expulsar no es deportar, Diario El Espectador (28 August 2015). http://www.elespectador.co $\mathrm{m} /$ noticias/elmundo/expulsar-no-deportar-articulo-582359

ARÉVALO, WALTER, ¿Quéherramientas diplomáticas existen para enfrentar la crisis?, Razón Pública (Bogotá, May 2015). http://www.razonpublica.com/index.php/internacional-temas-32/8789-colombia-venezuela-\%BFqu\% E9-herramientas-diplom\%E1 ticas-existen-para-enfrentar-la-crisis.html

BBC NEWS, International, Venezuelans Cross into Colombia to Buy Food, BBC News (London, 10 July 2016). http: //www.bbc.com/news/world-latin-america-36759102

CARACOL RADIO, Editorial, Venezuela reactiva deportaciones, Caracol News (Bogotá, 4 May 2016). Available at h ttp://caracol.com.co/emisora/2016/05/04/cucuta/1462317251_993090.html

DIARIO EL PAÍS, Frontpage, Anuncian medidas para corredor humanitario con Venezuela, Diario El Pais (Cali, 19 January 2016). http://www.elpais.com.co/elpais/colombia/noticias/anuncian-nuevas-medidas-para-corred or-humanitario-con-venezuela

NATIONAL POST, International, The Latest: Colombia Leader Won't Recognize Venezuela's Vote, National Post (Washington, 28 July 2017). https://nationalpost.com/pmn/news-pmn/the-latest-colombia-temporary-legal-s tatus-for-venezuelans

NOTICIAS AL DÍA, International News Section, Alcalde de Cúcuta dice que denunciará a Maduro ante la Corte Penal Internacional, Noticias al Dia (2 September 2015).

ROSATI, ANDREW, Venezuela Tags ' $D$ ' for Demolition on Illegal Border Homes, Bloomberg (26 August 2015). http://www.bloomberg.com/news/articles/2015-08-27/venezuela-marks-d-for-demolition-on-illegal-i mmigrants-houses

\section{Internet}

http://indicators.ohchr.org/

\section{Notes}

* Reflection article

1 UNITED NATIONS, INTERNATIONAL LAW COMMISSION, ILC, Preliminary Report on Diplomatic Protection, by Mr. MOHAMED BENNOUNA, Special Rapporteur, particularly at para. 47 (UN Doc. A/CN.4/484, 4 February 1998) (hereinafter, Preliminary Report).

2 UNITED NATIONS, INTERNATIONAL LAW COMMISSION, ILC, First Report on Diplomatic Protection, by Mr. JOHN R. DUGARD, Special Rapporteur (UN Doc. A/CN.4/506 and Add. 1, 7 March and 20 April, 2000) (hereinafter, Dugard First Report).

$3 \quad I b i d .$, para. 21.

$4 \quad I b i d .$, para. 29.

5 CARACOL RADIO, Editorial, Venezuela reactiva deportaciones, Caracol News (Bogotá, 4 May 2016). Available at http:// caracol.com.co/emisora/2016/05/04/cucuta/1462317251_993090.html

6 BBC NEWS, International, Venezuelans Cross into Colombia to Buy Food, BBC News (London, 10 July 2016). http://www .bbc.com/news/world-latin-america-36759102

7 NATIONAL POST, International, The Latest: Colombia Leader Won't Recognize Venezuela's Vote, National Post (Washington, 28 July 2017). https://nationalpost.com/pmn/news-pmn/the-latest-colombia-temporary-legal-status-for-venezue lans 
8 AURA XIMENA OSORIO-TORRES, Los derechos de los colombianos en el extranjero y de los extranjeros en Colombia. En mora de un enfoque integral, 117 Vniversitas, 357-376 (2008).

9 DIARIO EL PAÍS, Frontpage, Anuncian medidas para corredor humanitario con Venezuela, Diario El Pais (Cali, 19 January 2016). http://www.elpais.com.co/elpais/colombia/noticias/anuncian-nuevas-medidas-para-corredor-humanitario-con-venezuel

10 UNITED NATIONS HIGH COMMISSIONER FOR REFUGEES, UNHCR, Handbook for Repatriation and Reintegration Activities (UNHCR, Geneva, May 2004).

11 NOTICIAS AL DÍA, INTERNATIONAL NEWS SECTION, Alcalde de Cúcuta dice que denunciará a Maduro ante la Corte Penal Internacional, Noticias al Dia (2 September 2015).

12 Diplomatic Immunity is specifically covered under the Vienna Convention of Diplomatic Relations (VCDR 1961), Article 29 of which covers, specifically the immunity of diplomatic personnel from prosecution in the host state. United Nations, Vienna Convention of Diplomatic Relations (VCDR 1961), done at Vienna on 18 April 1961, entered into force on 24 April 1964.

13 IAN BROWNLIE, Principles of Public International Law, 391 ( $6^{\text {th }}$ ed., Oxford University Press, Oxford, 2003), where BROWNLIE characterizes this proposition of law as "trite".

14 ROBERT JOSEPH BLAISE MACLEAN, Fresh Hay from Old Fields: the Continuing Usefulness of Diplomatic Protection, in Derecho internacional contemporáneo: lo público, lo privado, los derechos humanos: liber amicorum en homenaje a Germán Cavelier, 230-246 (RICARDO ABELLO-GALVIS, ed., Universidad del Rosario, Bogotá, 2006).

15 Permanent Court of International Justice, PCIJ, Mavrommatis Palestine Concessions (Greece v. United Kingdom), Objection to the Jurisdiction of the Court, Judgment, PCIJ, Series A no 2, ICGJ 236, 30 August 1924, PCIJ 1924, 1-37.

16 Ibid., para. 1.

17 UNITED NATIONS, INTERNATIONAL LAW COMMISSION, ILC, First Report on Diplomatic Protection, by Mr. JOHN R. DUGARD, Special Rapporteur (UN Doc. A/CN.4/506 and Add. 1, 7 March and 20 April, 2000).

18 Ibid., paras. 20, 21.

19 Ibid., para. 29.

20 See UNITED NATIONS, INTERNATIONAL LAW COMMISSION, ILC, First Report on Diplomatic Protection, by Mr.JOHN R. DUGARD, Special Rapporteur (UN Doc. A/CN.4/506 and Add. 1, 7 March and 20 April, 2000), para. 75 as to the traditional position, International Court of Justice, ICJ, Barcelona Traction Light and Power Company Ltd. (Belgium v. Spain), Judgment of 5 February 1970, ICJ Reports, 1-54,44. And COLIN WARBRICK, Protection of Nationals Abroad, 37 International \& Comparative Law Quarterly, 4, 1002-1012 (1988), in reference to the British Rules.

21 COLIN WARBRICK \& DOMINIC MCGOLDRICK, Diplomatic Representations and Diplomatic Protection, 51 International \& Comparative Law Quarterly, 3, 723-733, 731 (2002). https://doi.org/10.1093/iclq/51.3.723 (hereinafter, Diplomatic Representations). This does not, of course, preclude the right of States to grant this right to their citizens under domestic law.

22 Both DUGARD and BENNOUNA included this idea as one of the "legal fictions" underlying diplomatic protection. Put another way, the Colombians being expelled from Venezuela are much more directly injured than the Republic of Colombia, yet in order to sustain this remedy in this case it would be necessary to argue that it is Colombia which has been wronged.

23 See IAN BROWNLIE, Principles of Public International Law, 526 (2003). The theory is that to grant an alien a higher standard than nationals would violate principles of national sovereignty because the alien would thereby be granted a kind of have special status.

24 Ibid., 527.

25 Mexico-US General Claims Commission, L. F. H. Neer and Pauline Neer (USA) v. United Mexican States (United States v. Mexico), 15 October 1926, 1926 Reports of International Arbitral Awards, RIAA IV, 60-66, 61-62.

26 COLIN WARBRICK \& DOMINIC MCGOLDRICK, Diplomatic Representations..., 51 International \& Comparative Law Quarterly, 3, 723-733, 726 (2002). 
IAN BROWNLIE, Principles of Public International Law, 526-531 (2003).

28 BROWNLIE included this as a type of international wrong that is contemplated under this head. Ibid., 526-531.

29 ANDREW ROSATI, Venezuela Tags 'D' for Demolition on Illegal Border Homes, Bloomberg (26 August 2015). http://ww w.bloomberg.com/news/articles/2015-08-27/venezuela-marks-d-for-demolition-on-illegal-immigrants-houses

30 United Nations, International Covenant on Civil and Political Rights, ICCPR, adopted and opened for signature, ratification and accession by General Assembly Resolution 2200A (XXI) of 16 December 1966, entry into force 23 March 1976.

31 Ibid., article 13.

32 http://indicators.ohchr.org/

33 GERALD HECKMAN, International Law and Procedural Safeguards in Deportation Proceedings: Ahani v. Canada, 17 Revue Québécoise de Droit International, 2, 81-122 (2000).

34 WALTER ARÉVALO, ¿Qué herramientas diplomáticas existen para enfrentar la crisis?, Razón Pública (Bogotá, May 2015). http://www.razonpublica.com/index.php/internacional-temas-32/8789-colombia-venezuela-\%BFqu\%E9-herramientasdiplom\%E1 ticas-existen-para-enfrentar-la-crisis.html

35 JEAN-MARIE HENCKAERTS, Mass Expulsion in Modern International Law and Practice (International Studies in Human Rights, volume 41, Martinus Nijhoff Publishers, The Hague, Boston, London, 1995).

36 United Nations, Human Rights Committee, Francesco Madafferi v. Australia, CCPR/C/81/D/1011/2001, 26 July 2004.

37 UNITED NATIONS, HUMAN RIGHTS COMMITTEE, HRC, General Comment 31 [80], The Nature of the General Legal Obligation Imposed on States Parties to the Covenant (CCPR/C/21/Rev.1/Add. 13, adopted on 29 March 2004). OFFICE OF THE UNITED NATIONS HIGH COMMISSIONER FOR HUMAN RIGHTS, OHCHR, Expulsions of Aliens in International Human Rights Law, Discussion paper, Geneva, September 2006.

38 OFFICE OF THE UNITED NATIONS HIGH COMMISSIONER FOR HUMAN RIGHTS, OHCHR, Expulsions of Aliens in International Human Rights Law, September 2006.

$39 \quad$ Ibid., 526.

40 CHRISTA MEINDERSMA, Violations of Common Article 3 of the Geneva Conventions as Violations of the Laws or Customs of War under Article 3 of the Statute of the International Criminal Tribunal for the Former Yugoslavia, 42 Netherlands International Law Review, 03, 375-397 (1995). https://doi.org/10.1017/S0165070X00005891

41 DARRYL ROBINSON, Defining \#Crimes against Humanity\# at the Rome Conference, 93 American Journal of International Law, 1, 43-57 (1999). https://doi.org/10.2307/2997955

42 MATTHEW J. GIBNEY, Is Deportation a Form of Forced Migration?, 32 Refugee Survey Quarterly, 2, 116-129 (2013). h ttps://doi.org/10.1093/rsq/hdt003

43 WALTER ARÉVALO, Expulsar no es deportar, Diario El Espectador (28 August 2015). http://www.elespectador.com/no ticias/elmundo/expulsar-no-deportar-articulo-582359

44 JAMES CRAWFORD, The International Law Commission's Articles on State Responsibility. Introduction, Text and Commentaries (Cambridge University Press, Cambridge, 2002).

45 UNITED NATIONS, INTERNATIONAL LAW COMMISSION, ILC, Draft Articles on Responsibility of States for Internationally Wrongful Acts by the (Supplement No. 10 (A/56/10), chp.IV.E.1, November 2001).

46 See, e.g., UNITED NATIONS, INTERNATIONAL LAW COMMISSION, ILC, First Report on Diplomatic Protection, by Mr. JOHN R. DUGARD, Special Rapporteur (UN Doc. A/CN.4/506 and Add. 1, 7 March and 20 April, 2000) (hereinafter, Dugard First Report), the subject of which is "Exhaustion of Local Remedies", and JAMES EDMUND SANDFORD FAWCETT, The Exhaustion of Local Remedies: Substance or Procedure?, 31 British Yearbook of International Law, $452-458$ (1954).

47 International Court of Justice, ICJ, Elettronica Sicula S.p.A. Case (ELSI) (United States of America v. Italy), Judgment of 20 July 1989, ICJ Reports, 1-71, para. 59. 
48 UNITED NATIONS, INTERNATIONAL LAW COMMISSION, ILC, Third Report on Diplomatic Protection, by Mr. JOHN R. DUGARD, Special Rapporteur, para. 23 (UN Doc. A/CN.4/523 and Add.1,7 March and 16 April 2002). Also, COLIN WARBRICK \& DOMINIC MCGOLDRICK, supra note 26 in which the author cites the British Foreign Office's rules regarding the exercise of diplomatic protection, which are to the same effect.

49 JAMES EDMUND SANDFORD FAWCETT, The Exhaustion of Local Remedies..., 31 British Yearbook of International Law, 452-458, 452 (1954).

50 Ibid., 453.

51 UNITED NATIONS, INTERNATIONAL LAW COMMISSION, ILC, First Report on Diplomatic Protection, by Mr. JOHN R. DUGARD, Special Rapporteur, para. 32-40 (UN Doc. A/CN.4/506 and Add. 1, 7 March and 20 April, 2000).

52 JAMES EDMUND SANDFORD FAWCETT, The Exhaustion of Local Remedies..., 31 British Yearbook of International Law, 452-458, 453 (1954).

53 UNITED NATIONS, INTERNATIONAL LAW COMMISSION, ILC, Second Report on Diplomatic Protection, by Mr. JOHN R. DUGARD, Special Rapporteur, para. 33 (UN Doc. A/CN.4/514, 28 February 2001).

54 SONJA STARR \& LEA BRILMAYER, Family Separation as a Violation of International Law, 21 Berkeley Journal of International Law, 2, 213-287 (2003). https://doi.org/10.15779/Z388350

55 UNITED NATIONS, INTERNATIONAL LAW COMMISSION, ILC, Second Report on Diplomatic Protection, by Mr. JOHN R. DUGARD, Special Rapporteur (UN Doc. A/CN.4/514, 28 February 2001).

56 Referred to as the Continuous Nationality Rule. See GUY I. F. LEIGH, Nationality and Diplomatic Protection, 20 International \& Comparative Law Quarterly, 3, 453-475, 456 (1971). Cf. MATTHEW S. DUCHESNE, The ContinuousNationality-of-Claims Principle..., 36 George Washington International Law Review, 4, 783-816 (2004) in which the author disputes whether continuous nationality is, in fact, a rule.

57 IAN BROWNLIE, Principles of Public International Law, 390 (2003).

58 Permanent Court of International Justice, PCIJ, The Panevezys-Saldutiskis Railway Case (Estonia v. Lithuania), Judgment of 28 February 1939 (Series A/B) No. 76 (1939), 1939 PCIJ, 1-23.

59 Ibid., 16.

60 MATTHEW S. DUCHESNE, The Continuous-Nationality-of-Claims Principle..., 36 George Washington International Law Review, 4, 783-816, 792 (2004). DUCHESNE points to this as another example of the legal fictions underlying Diplomatic Protection.

61 See IAN BROWNLIE, Principles of Public International Law, 405-406 (2003). In his discussion about "effective nationality" he opines that the results of accepting effective nationality may not be "radical". It is important to point out, however, that it will be in those few cases in which a State exercises diplomatic protection against a national's former State that the distinction between "equality" and effective nationality" will be most important.

62 See UNITED NATIONS, INTERNATIONAL LAW COMMISSION, ILC, First Report on Diplomatic Protection, by Mr. JOHN R. DUGARD, Special Rapporteur, 123 (UN Doc. A/CN.4/506 and Add. 1, 7 March and 20 April, 2000). In such cases, the "equality" approach would permit the offending State to preclude the State of new nationality from exercising diplomatic protection by the mere expedient of disallowing a victim from renouncing nationality.

63 International Court of Justice, ICJ, Nottebohm Case (Liechtenstein v. Guatemala) (second phase), Judgment of 6 April 1955, ICJ Reports, 1-27.

64 The alacrity with which Mr. Nottebohm was able to receive his naturalization led to suspicions of fraud; however, this did not form the stated basis of the decision. Nonetheless, once he became a naturalized citizen of Liechtenstein, Nottebohm lost his German nationality by operation of German law. See GUY I. F. LEIGH, Nationality and Diplomatic Protection, 20 International \& Comparative Law Quarterly, 3, 453-475, 456-466 (1971).

65 International Court of Justice, ICJ, Nottebohm Case (Liechtenstein v. Guatemala) (second phase), Judgment of 6 April 1955, ICJ Reports, 1-27, 23. 
67 See GUY I. F. LEIGH, Nationality and Diplomatic Protection, 20 International \& Comparative Law Quarterly, 3, 453-475, 469 (1971), where he states: "It is clear that the Nottebohm case has given renewed vigour to the principle of effectiveness. Further, it is clear, that this may have the effect of ensuring that a State may bring a claim on behalf of a national effectively connected with it, even when the claim is against another State of which the individual is formally a national." See also JONATHAN SHIRLEY, The Role of International Human Rights and the Law of Diplomatic Protection in Resolving Zimbabwe's Land Crisis, 27 Boston College of International and Comparative Law Review, 1, 161-171, 170 (2004). There, the writer in discussing the availability of diplomatic protection for dual British-Zimbabwe white farmers. He asserts that the dual nationals "...must demonstrate that their dominant and effective nationality is that of the United Kingdom and not Zimbabwe."

68 UNITED NATIONS, INTERNATIONAL LAW COMMISSION, ILC, Sixth Report on Diplomatic Protection, by Mr. JOHN R. DUGARD, Special Rapporteur (UN Doc. A/CN.4/546, 11 August 2004).

69 Ibid., para. 18.

\section{Licencia Creative Commons CC BY 4.0}

To cite this article / Para citar este articulo: MACLEAN, ROBERT JOSEPH BLAISE \& ARÉVALORAMÍREZ, WALTER, The Expulsion of Resident Colombian Nationals during the Colombia-Venezuela Border Dispute: An "Under the Radar" Case for Diplomatic Protection of Human Rights?, 138 Vniversitas (2019). https://doi.org/10.11144/Javeriana.vj138.ercn 